\title{
Efficient Synthesis of Novel 4'-Trifluoromethyl-5'-norcarbocyclic Purine Phosphonic Acid Analogs by Using the Ruppert-Prakash Reaction
}

\author{
Seyeon Kim, Eunae Kim, Jin Cheol Yoo, and Joon Hee Hong* \\ BK-21 Project Team, College of Pharmacy, Chosun University, Kwangju 501-759, Korea. *E-mail: hongjh@chosun.ac.kr \\ Received May 13, 2014, Accepted May 21, 2014
}

\begin{abstract}
Novel 4'-trifluoromethyl-5'-norcarbocyclic purine phosphonic acid analogs were efficiently synthesized from commercially available 1,3-dihydroxy cyclopentane (5). Trifluoromethylation was successfully performed by using the Ruppert-Prakash reaction. The purine nucleosidic bases were efficiently coupled by using the Mitsunobu reaction. The synthesized adenosine phosphonic acids analogs $\mathbf{1 3}$ and $\mathbf{1 6}$ were screened for antiviral activity against human immunodeficiency virus-1 (HIV-1). Adenine derivative $\mathbf{1 3}$ exhibited significant antiHIV-1 activity.
\end{abstract}

Key Words : Anti-HIV agents, 4'-Branched carbocyclic nucleoside, Phosphonic acid nucleosides

\section{Introduction}

4'-Branched-5'-norcarbocyclic phosphonic acid analogs, such as 4 '-vinyl-cpAP (1) ${ }^{1}$ and 4 '-ethynyl-cpAP $(2){ }^{2}$ have encouraged the search for novel nucleosides as potential anti-human immunodeficiency virus (HIV) agents among this class of compounds. Molecular modeling studies demonstrated the presence of a hydrophobic 4'-pocket that could accommodate these substitutions and enhance anti-HIV activity. ${ }^{1}$

Although monofluorinated ${ }^{3}$ and gem-difluorinated ${ }^{4}$ nucleosides have been widely studied, only a few trifluoromethylated $^{5}$ nucleosides have been reported, which is probably because of the limitations of existing synthesis methods. The presence of a $\mathrm{CF}_{3}$ group on the sugar moiety of nucleosides could confer many advantages including increased lipophilicity $^{6}$ and improved chemical and/or enzymatic stability. ${ }^{7}$ In addition, the trifluoromethyl group can enhance the therapeutic properties of bioactive compounds. ${ }^{8}$ There has been increased interest in introducing a trifluoromethyl group into nucleosides in order to discover new nucleoside derivatives with high antiviral activities. Li et al. (2001) reported the first synthesis of $2^{\prime}-C$ - $\beta$-trifluoromethyl pyrimidine ribonucleoside (3) with the Ruppert-Prakash reagent. ${ }^{9}$ Johnson and Kozak successfully synthesized a 4'-trifluoromethylated nucleoside analog (4) by introducing a $\mathrm{CF}_{3}$ group into the $\mathrm{C}$ 4 ' position of ribose derivatives (Figure 1). ${ }^{10}$

Phosphonate has certain advantages over its phosphate counterpart, as it is metabolically stable because of its phosphorus-carbon bond, which is not susceptible to hydrolytic cleavage. ${ }^{11}$ The spatial location of the oxygen atom, the $\beta$ position from the phosphorus atom in the nucleoside analog, is critical for antiviral activity. The increased antiviral activity conferred by the oxygen atom may be attributed to the increased binding capacity of the phosphonate analog to target enzymes. ${ }^{12}$ Moreover, a phosphonate nucleoside does not require the first phosphorylation, which is a crucial step for the activation of nucleosides. This is frequently a limit-<smiles>C=CC1(OCP(=O)(O)O)C=CC(n2cnc3c(N)ncnc32)C1</smiles><smiles>C#CC1(OCP(=O)(O)O)C=CC(n2cnc3c(N)ncnc32)C1</smiles>

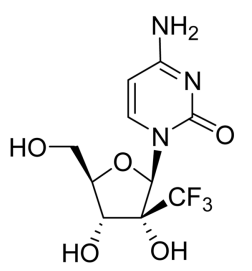

(3)

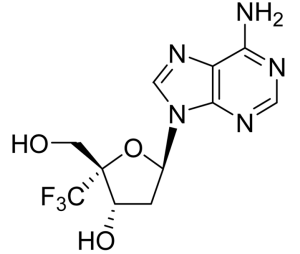

(4)
Figure 1. Design rationale of 4'-trifluoromethyl-5'-norcarbocyclic phosphonic acid nucleoside analogs.

ing step in the phosphorylation sequence, which ultimately leads to triphosphates. ${ }^{13}$

Given that 4'-branched nucleoside analogs and 5'-norcarbocyclic nucleoside phosphonate have excellent biological activities, we aimed to synthesize a novel class of nucleosides, including 4'-trifluoromethyl-5'-norcarbocyclic phosphonic acid analogs, in order to identify more effective therapeutics against HIV and to provide analogs for probing the conformational preferences of enzymes associated with the nucleoside kinases of nucleosides and nucleotides.

As depicted in Scheme 1, the target compounds were readily prepared from 1,3-dihydroxy cyclopentane (5). Selective monosilylation of diol $\mathbf{5}$ produced alcohol derivative $\mathbf{6}$, which was oxidized to the ketone 7 by using Dess-Martin conditions. ${ }^{14}$ Lavaire et al. (1996) reported fluoride-induced trifluoromethylation conditions by using the RuppertPrakash reagent, in which the tert-butyldimethylsilyl (TBDMS) protective group is retained. ${ }^{15}$ The ketone 7 was subjected to nucleophilic addition conditions ${ }^{16}$ with $\mathrm{CF}_{3} \mathrm{SiMe}_{3} / t$-butyl- 

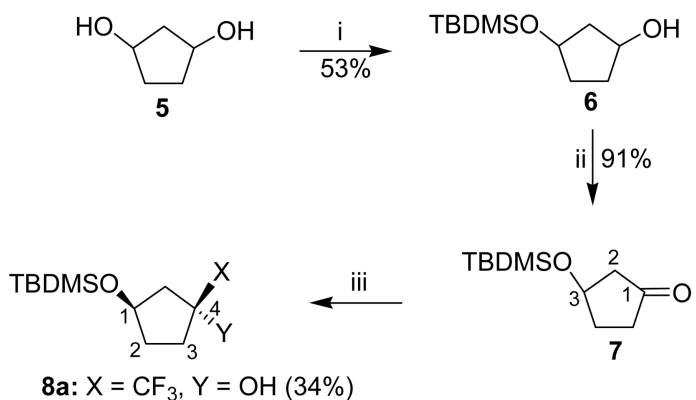

8a: $X=\mathrm{CF}_{3}, Y=\mathrm{OH}(34 \%)$
8b: $X=O H, Y=\mathrm{CF}_{3}(35 \%)$

Reagents: i) TBDMSCl, imidazole, $\mathrm{CH}_{2} \mathrm{Cl}_{2},-10{ }^{\circ} \mathrm{C}$;

ii) Dess-Martin periodinane, $\mathrm{CH}_{2} \mathrm{Cl}_{2}$; iii) (a) $\mathrm{CF}_{3} \mathrm{SiMe}_{3}$, TBAF (cat), THF; (b) Na (cat), MeOH.

Scheme 1. Synthesis of trifluoromethylated cyclopentanol intermediate.

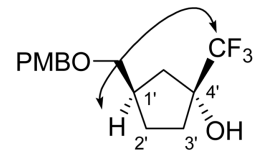

$8 a$

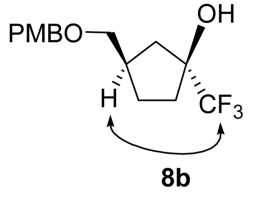

$8 \mathrm{~b}$
Figure 2. ${ }^{19} \mathrm{~F}-1 \mathrm{H}$ NOE differences between the proximal hydrogens of $8 \mathbf{a}$ and $8 \mathbf{b}$.

ammonium fluoride (TBAF) followed by treatment with $\mathrm{NaOMe}$ in $\mathrm{MeOH}$, and to give the cyclopentanols 8a (34\%) and $\mathbf{8 b}(35 \%)$. The stereochemical assignment of $\mathbf{8 a}$ and $\mathbf{8 b}$ as $\alpha$ and $\beta$ anomers, respectively, was determined by the ${ }^{19} \mathrm{~F}$ ${ }^{1} \mathrm{H}$ nuclear Overhauser effects (NOE) experiments. For $\mathbf{8 b}$, we observed strong NOE signals for ${ }^{1} \mathrm{H}$ when the ${ }^{19} \mathrm{~F}$ nuclei were irradiated (Figure 2).

The hydroxyl functional group of $\mathbf{8 b}$ was treated with diethylphosphonomethyl triflate ${ }^{17}$ by using lithium $t$-butoxide to yield the phosphonate analog 9 (Scheme 2). Removal of the silyl protective group of 9 by using TBAF produced the secondary alcohol 10. To synthesize the desired 5'-norcarbocyclic adenosine nucleoside analogs, the cyclopentanol 10 was treated with 6-chloropurine under Mitsunobu conditions ${ }^{18}$ [diethyl azodicarboxylate (DEAD) and $\mathrm{PPh}_{3}$ ]. Slow addition of DEAD to a mixture of cyclopentanol 10, triphenylphosphine, and the 6-chloropurine in anhydrous tetrahydrofuran (THF) solvent produced a yellow solution, which was stirred for $2 \mathrm{~h}$ at $-40{ }^{\circ} \mathrm{C}$ and further stirred overnight at room temperature to produce the protected 6-chloropurine analog 11 as a single $N^{9}$-regioisomer (UV $[\mathrm{MeOH}] \lambda_{\max }$ $264.0 \mathrm{~nm}$ ). ${ }^{19}$ The chlorine group of $\mathbf{1 1}$ was then converted to an amine group with methanolic ammonia at $72{ }^{\circ} \mathrm{C}$ to produce the corresponding adenine phosphonate derivative $\mathbf{1 2}$. Hydrolysis of 12 by treatment with bromotrimethylsilane (TMSBr) in $\mathrm{CH}_{3} \mathrm{CN}$ in the presence of 2,6-lutidine produced an adenine phosphonic acid derivative $\mathbf{1 3}$ (Scheme 2). ${ }^{20}$

For the synthesis of guanine analogs, 2-fluoro-6-chloropurine $^{21}$ was condensed with alcohol derivative $\mathbf{1 0}$ under similar coupling conditions as those used for the condensation of 6-chloropurine to produce the 2-fluoro-6-chloropurine analog 14 (61\% yield). Bubbling ammonia into
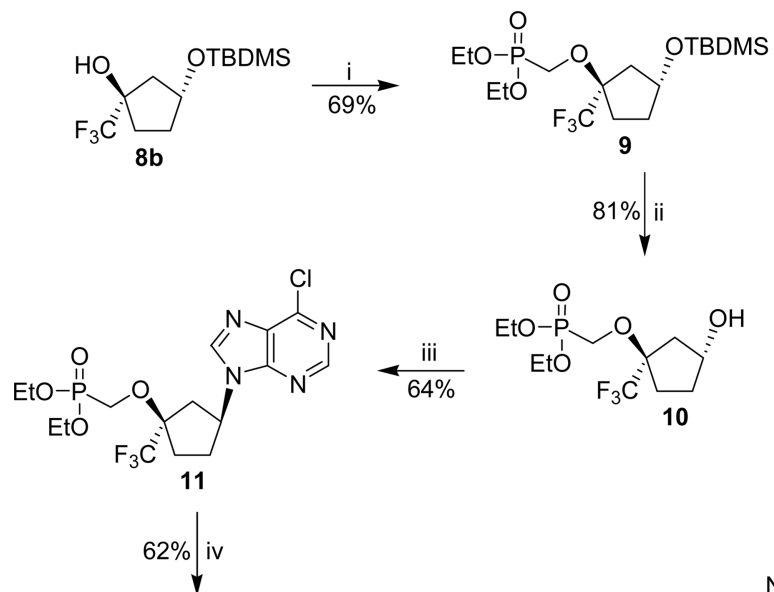<smiles></smiles>

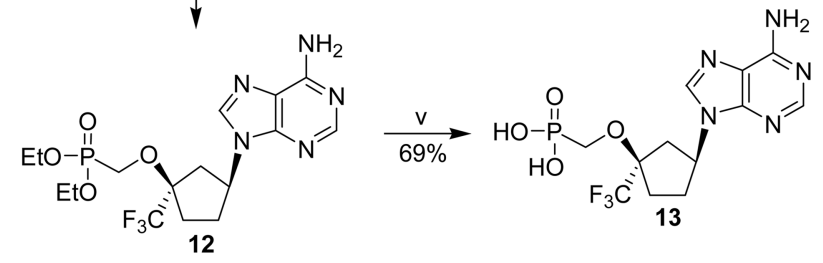

Reagents: i) (EtO) ${ }_{2} \mathrm{POCH}_{2} \mathrm{OTf}$, LiO-t-Bu, THF; ii) TBAF, THF; iii) 6chloropurine, DEAD, $\mathrm{PPh}_{3}$, THF; iv) $\mathrm{NH}_{3} / \mathrm{MeOH}, 70^{\circ} \mathrm{C}$; v) $\mathrm{TMSBr}$, 2,6lutidine, $\mathrm{CH}_{3} \mathrm{CN}$.

Scheme 2. Synthesis of 5'-norcarbocyclic adenine phosphonic acid.

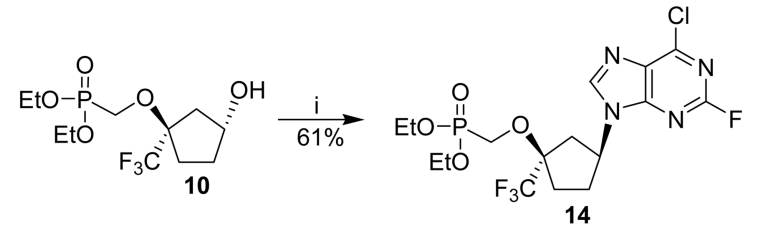

$$
\begin{aligned}
& \downarrow^{i i} x
\end{aligned}
$$

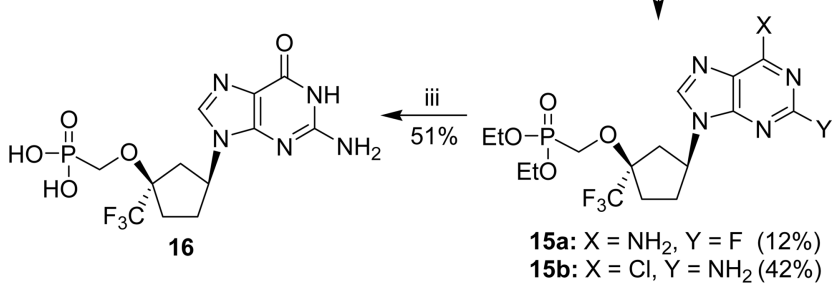

Scheme 3. Synthesis of 5'-norcarbocyclic guanine phosphonic acid.

compound 14 produced the 2-fluoro-6-aminopurine analog 22 15a and 2-amino-6-chloropurine analog $15 \mathbf{b}$ with $12 \%$ and $42 \%$ yields, respectively. The 2-amino-6-chloropurine derivative $\mathbf{1 5 b}$ was treated with TMSBr and 2,6-lutidine to produce the corresponding phosphonic acid, which was successively treated with sodium methoxide and 2-mercaptoethanol in $\mathrm{MeOH}$ resulting in the desired guanine phosphonic acid 16 (Scheme 3). ${ }^{23}$

The synthesized nucleoside phosphonic acid analogs $\mathbf{1 3}$ and $\mathbf{1 6}$ were then evaluated for antiviral activity against 
Table 1. Anti-HIV activity of synthesized compounds

\begin{tabular}{ccc}
\hline $\begin{array}{c}\text { Compound } \\
\text { No. }\end{array}$ & $\begin{array}{c}\text { anti-HIV } \\
\mathrm{EC}_{50}(\mu \mathrm{M})^{c}\end{array}$ & $\begin{array}{c}\text { Cytotoxicity } \\
\mathrm{CC}_{50}(\mu \mathrm{M})^{d}\end{array}$ \\
\hline 13 & 8.4 & 90 \\
16 & 39.2 & 98 \\
AZT $^{a}$ & 0.009 & 100 \\
PMEA $^{b}$ & 0.54 & 10 \\
\hline
\end{tabular}

${ }^{a}$ AZT: azidothymidine. ${ }^{b}$ PMEA: 9-(2-[phosphonomethoxy]ethyl)adenine. ${ }^{c} \mathrm{EC}_{50}(\mu \mathrm{M})$ : Concentration $(\mu \mathrm{M})$ required to inhibit the replication of HIV-1 by $50 \% .{ }^{d} \mathrm{CC}_{50}(\mu \mathrm{M})$ : Concentration $(\mu \mathrm{M})$ required to reduce the viability of unaffected cells by $50 \%$

HIV-1. The antiviral activity of phosphonate nucleosides is due to their intracellular metabolism to diphosphates followed by incorporation into the viral genome and chain termination. ${ }^{24}$ Anti-HIV activity was determined in human peripheral blood mononuclear $(\mathrm{PBM})$ cells infected with HIV-1 strain LAI. PBM cells $\left(1 \times 10^{5}\right.$ cell $\left./ \mathrm{mL}\right)$ were infected with HIV-1 at a multiplicity of infection of 0.02 and cultured in the presence of different concentrations of the test compounds. After 4 days of incubation at $37^{\circ} \mathrm{C}$, numbers of viable cells were determined by using the 3-(4,5-di-methylthiazole-2-yl)-2,5-diphenyltetrazolium bromide method. The cytotoxicity of the compounds was evaluated in parallel with their antiviral activity, based on the viability of mockinfected cells. ${ }^{25}$ In particular, the adenine analog 13 showed significant anti-HIV-1 activity (Table 1), indicating diphosphorylation of the sugar moiety of the analog or some affinity of viral polymerases for its diphosphate. However, guanine nucleoside analog 16 showed weak anti-HIV activity at concentrations of up to $100 \mu \mathrm{M}$.

In summary, we have designed and successfully synthesized novel 4'-trifluoromethyl-5'-norcarbocyclic phosphonic acid nucleoside analogs starting from 1,3-dihydroxy cyclopentane (5). The adenine analog 13 exhibited significant antiviral activity against HIV-1 $\left(\mathrm{EC}_{50}=8.4 \mu \mathrm{M}\right)$.

\section{Experimental Section}

Melting points (mp) were determined by using a Meltemp II laboratory device and are uncorrected. Nuclear magnetic resonance (NMR) spectra were recorded on a JEOL 300 Fourier transform spectrometer (JEOL, Tokyo, Japan). Chemical shifts are reported in parts per million (d) and signals are reported as s (singlet), d (doublet), $\mathrm{t}$ (triplet), $\mathrm{q}$ (quartet), $\mathrm{m}$ (multiplet), and dd (doublet of doublets). Ultraviolet (UV) spectra were obtained on a Beckman DU-7 spectrophotometer (Beckman, South Pasadena, CA, USA). Mass spectrometry (MS) spectra were collected in the electrospray ionization mode. The elemental analyses were performed by using a Perkin-Elmer 2400 analyzer (PerkinElmer, Norwalk, CT, USA). Thin layer chromatography was performed on Uniplates (silica gel) purchased from Analtech Co. (7558, Newark, DE, USA). All reactions were carried out under a nitrogen atmosphere unless otherwise specified. Dry dichloromethane, benzene, and pyridine were obtained by distillation from $\mathrm{CaH}_{2}$. Dry THF was obtained by distillation from $\mathrm{Na}$ and benzophenone immediately prior to use.

(rel)-(1S and 1R,3S)-3-(t-Butyldimethylsilanyloxy) cyclopentanol (6). TBDMSCl (2.29 $\mathrm{g}, 15.25 \mathrm{mmol})$ was added slowly to a solution of $\mathbf{5}(1.41 \mathrm{~g}, 13.87 \mathrm{mmol})$ and imidazole (1.41 g, $20.80 \mathrm{mmol})$ in $\mathrm{CH}_{2} \mathrm{Cl}_{2}(100 \mathrm{~mL})$ at $-10^{\circ} \mathrm{C}$ and stirred for $7 \mathrm{~h}$ at the same temperature. Saturated $\mathrm{NaHCO}_{3}$ solution $(10 \mathrm{~mL})$ was poured into the mixture and stirred for $1 \mathrm{~h}$ at room temperature. The solvent was evaporated under reduced pressure. The residue was dissolved in water (200 $\mathrm{mL})$ and extracted with diethyl ether $(200 \mathrm{~mL})$. The organic layer was washed with brine, dried over anhydrous $\mathrm{MgSO}_{4}$, filtered, and concentrated under reduced pressure. The residue was purified by silica gel column chromatography (EtOAc/hexane, 1:10) to produce compound 6 (1.58 g, 53\%) as an isomeric mixture: ${ }^{1} \mathrm{H} \mathrm{NMR}\left(\mathrm{CDCl}_{3}, 300 \mathrm{MHz}\right) \delta 3.27-$ $3.20(\mathrm{~m}, 2 \mathrm{H}), 1.98-1.52(\mathrm{~m}, 6 \mathrm{H}), 0.89(\mathrm{~m}, 9 \mathrm{H}), 0.02(\mathrm{~m}, 6 \mathrm{H})$.

$( \pm)-3-(t$-Butyldimethylsilanyloxy) Cyclopentanone (7). Compound 6 (2.43 g, $11.25 \mathrm{mmol})$ was added to a solution of Dess-Martin periodinane (10.38 g, $24.5 \mathrm{mmol})$ in $\mathrm{CH}_{2} \mathrm{Cl}_{2}$ $(100 \mathrm{~mL})$ at $0{ }^{\circ} \mathrm{C}$, and stirred for $24 \mathrm{~h}$ at room temperature under argon gas. The solvent was removed and the residue was triturated with diethyl ether $(150 \mathrm{~mL})$. Following filtration through a pad of silica gel, the organic solution was washed with a solution of sodium thiosulfate pentahydrate $(13 \mathrm{~g})$ in water $(100 \mathrm{~mL})$, ice-cold saturated $\mathrm{NaHCO}_{3}(80$ $\mathrm{mL})$, and brine $(80 \mathrm{~mL})$ and dried over $\mathrm{MgSO}_{4}$. The solvent was filtered, concentrated under vacuum, and purified by silica gel column chromatography (EtOAc/hexane, 1:10) to produce compound $7(2.19 \mathrm{~g}, 91 \%)$ as a colorless syrup: ${ }^{1} \mathrm{H}$ $\mathrm{NMR}\left(\mathrm{CDCl}_{3}, 300 \mathrm{MHz}\right) \delta$ 3.76-3.74 (m, 1H), 2.34-2.02 (m, $6 \mathrm{H}), 0.89(\mathrm{~s}, 9 \mathrm{H}), 0.03(\mathrm{~s}, 6 \mathrm{H}) ;{ }^{13} \mathrm{C} \mathrm{NMR}\left(\mathrm{CDCl}_{3}, 75 \mathrm{MHz}\right)$ $\delta$ 215.6, 63.5, 52.6, 37.1, 31.5, 25.7, 18.4, -4.7. Anal. Calcd. for $\mathrm{C}_{11} \mathrm{H}_{22} \mathrm{O}_{2} \mathrm{Si}$ : C, 61.63; H, 10.34; Found: C, 61.72; $\mathrm{H}$, 10.26; MS $m / z 215(\mathrm{M}+\mathrm{H})^{+}$.

(rel)-(1R,4S)-1-(t-Butyldimethylsilanyloxy)-4-(trifluoromethyl)cyclopentanyl-4-ol (8a) and (rel)-(1R,4R)-1-( $t$-butyldimethylsilanyloxy)-4-(trifluoromethyl)cyclopentanyl4-ol (8b). A catalytic amount of TBAF $(0.37 \mathrm{~mL}, 1 \mathrm{M}$ solution in THF) was added into mixture 7 (1.54 g, 7.2 mmol) with trifluoromethylsilane $(25 \mathrm{~mL}, 12.5 \mathrm{mmol}, 0.5 \mathrm{M}$ solution in THF $)$ in dry THF $(10 \mathrm{~mL})$ at $-78^{\circ} \mathrm{C}$ under argon gas. The reaction mixture was allowed to warm to room temperature. The solution became yellow immediately upon the addition of TBAF and eventually became dark brown. After the reaction mixture was stirred for $15 \mathrm{~h}$ at room temperature, it was washed with saturated $\mathrm{NH}_{4} \mathrm{Cl}$ solution. The aqueous layer was extracted with $\mathrm{Et}_{2} \mathrm{O}(2 \times 20 \mathrm{~mL})$ and the combined organic layer was dried with magnesium sulfate, filtered, and concentrated in vacuo. The residue was purified by flash column chromatography. Without further purification, the crude residue was dissolved in methanol (10 $\mathrm{mL})$ and a catalytic amount (0.1 eq) of metallic $\mathrm{Na}(17 \mathrm{mg})$ was added at $0{ }^{\circ} \mathrm{C}$. The reaction was completed within $1 \mathrm{~h}$, the reaction mixture was treated with a saturated $\mathrm{NH}_{4} \mathrm{Cl}$ solution, and the aqueous layer was extracted with $\mathrm{Et}_{2} \mathrm{O}$. The combined organic layer was dried over $\mathrm{Na}_{2} \mathrm{SO}_{4}$ and filtered. 
The solvent was concentrated under high vacuum and the residue was purified by silica gel column chromatography (EtOAc/hexane, 1:8) to produce 8a (695 mg, 34\%) and $\mathbf{8 b}$ (760 mg, 35\%) as oils. Compound 8a: ${ }^{1} \mathrm{H} \mathrm{NMR}\left(\mathrm{CDCl}_{3}, 300\right.$ $\mathrm{MHz}) \delta 3.25-3.23(\mathrm{~m}, 1 \mathrm{H}), 1.90-1.56(\mathrm{~m}, 6 \mathrm{H}), 0.90(\mathrm{~s}, 9 \mathrm{H})$, $0.02(\mathrm{~s}, 6 \mathrm{H}) ;{ }^{13} \mathrm{C} \mathrm{NMR}\left(\mathrm{CDCl}_{3}, 75 \mathrm{MHz}\right) \delta 140.4(\mathrm{q}, J=$ 283.7 Hz), 80.2 (q, $J=30.4 \mathrm{~Hz}), 68.5,35.2,29.8,25.5,19.3$, 18.4, -5. Anal. Calcd. for $\mathrm{C}_{12} \mathrm{H}_{23} \mathrm{~F}_{3} \mathrm{O}_{2} \mathrm{Si}$ : C, 50.68; H, 8.15; Found: C, 50.77; H, 8.21; MS m/z $285(\mathrm{M}+\mathrm{H})^{+}$.

Compound 8b: ${ }^{1} \mathrm{H}$ NMR $\left(\mathrm{CDCl}_{3}, 300 \mathrm{MHz}\right) \delta 3.37-3.34$ $(\mathrm{m}, 1 \mathrm{H}), 1.91-1.55(\mathrm{~m}, 6 \mathrm{H}), 0.89(\mathrm{~s}, 1 \mathrm{H}), 0.02(\mathrm{~s}, 6 \mathrm{H}) ;{ }^{13} \mathrm{C}$ NMR $\left(\mathrm{CDCl}_{3}, 75 \mathrm{MHz}\right) \delta 139.7(\mathrm{q}, J=282.8 \mathrm{~Hz}), 79.5(\mathrm{q}, J$ $=31.8 \mathrm{~Hz}), 66.8,36.2$, 30.2, 25.7, 19.5, 18.1, -4.4. Anal. Calcd. for $\mathrm{C}_{12} \mathrm{H}_{23} \mathrm{~F}_{3} \mathrm{O}_{2} \mathrm{Si}$ : C, 50.68; H, 8.15; Found: $\mathrm{C}$, 50.56; H, 8.08; MS m/z $285(\mathrm{M}+\mathrm{H})^{+}$.

(rel)-(1R,4R)-Diethyl 1-(t-butyldimethylsilanyloxy) 4[(trifluoromethyl) cyclopentanyloxy] methylphosphonate (9). Both $\mathrm{LiO} t$-Bu $(3.172 \mathrm{~mL}$ of $0.5 \mathrm{M}$ solution in THF, $1.586 \mathrm{mmol})$ and a solution of diethyl phosphonomethyltriflate $(475 \mathrm{mg}, 1.586 \mathrm{mmol}$ ) in $12.0 \mathrm{~mL}$ of THF were slowly added to a solution of the $\mathbf{8 b}$ analog (225 $\mathrm{mg}, 0.793$ mmol) in $6.0 \mathrm{~mL}$ of $\mathrm{THF}$ at $0{ }^{\circ} \mathrm{C}$ and stirred overnight at room temperature under anhydrous conditions. The mixture was quenched by adding saturated $\mathrm{NH}_{4} \mathrm{Cl}$ solution $(5 \mathrm{~mL})$ and further diluted with additional $\mathrm{H}_{2} \mathrm{O}(100 \mathrm{~mL})$. The aqueous layer was extracted with EtOAc $(3 \times 100 \mathrm{~mL})$. The combined organic layer was washed with brine, dried over anhydrous $\mathrm{MgSO}_{4}$, and concentrated in vacuo. The residue was purified by silica gel column chromatography (Hexane/ EtOAc, 4:1) to produce 9 (237 mg, 69\%): ${ }^{1} \mathrm{H} \mathrm{NMR}\left(\mathrm{CDCl}_{3}\right.$, $300 \mathrm{MHz}) \delta 4.38(\mathrm{~m}, 4 \mathrm{H}), 3.94(\mathrm{~d}, J=8.0 \mathrm{~Hz}, 2 \mathrm{H}), 3.26(\mathrm{~m}$, 1H), 1.89-1.49 (m, 6H), $1.13(\mathrm{~m}, 6 \mathrm{H}), 0.89$ (s, 9H), $0.04(\mathrm{~s}$, $6 \mathrm{H}) ;{ }^{13} \mathrm{C} \mathrm{NMR}\left(\mathrm{CDCl}_{3}, 75 \mathrm{MHz}\right) \delta 138.4(\mathrm{q}, J=281.4 \mathrm{~Hz})$, 85.3 (q, $J=28.2 \mathrm{~Hz}$ ), 70.1, 62.8, 62.3, 32.1, 30.5, 25.3, 18.6, 17.4, 13.7, -4.6. Anal. Calcd. for $\mathrm{C}_{17} \mathrm{H}_{34} \mathrm{~F}_{3} \mathrm{O}_{5} \mathrm{PSi}$ : C, 46.99; H, 7.89; Found: C, 47.11; H, 7.95; MS m/z $435(\mathrm{M}+\mathrm{H})^{+}$.

(rel)-(1R,4R)-Diethyl [4-(trifluoromethyl) cyclopentanyloxy] methylphosphonate (10). TBAF $(0.60 \mathrm{~mL}, 1.0 \mathrm{M}$ solution in THF) was added to a solution of 9 (235 mg, 0.54 $\mathrm{mmol})$ in $\mathrm{THF}(8 \mathrm{~mL})$ at $0{ }^{\circ} \mathrm{C}$. The mixture was stirred overnight at room temperature and concentrated. The residue was purified by silica gel column chromatography (EtOAc/hexane/MeOH, 1:4:0.02) to produce $10(140 \mathrm{mg}$, $81 \%$ ) as an oil: ${ }^{1} \mathrm{H}$ NMR (DMSO- $\left.d_{6}, 300 \mathrm{MHz}\right) \delta 4.41-4.38$ $(\mathrm{m}, 4 \mathrm{H}), 3.87(\mathrm{~d}, J=8.1 \mathrm{~Hz}, 2 \mathrm{H}), 3.31(\mathrm{~m}, 1 \mathrm{H}), 1.94-1.52$ $(\mathrm{m}, 6 \mathrm{H}), 1.11(\mathrm{~m}, 6 \mathrm{H}) ;{ }^{13} \mathrm{C}$ NMR (DMSO-d $\left.6,75 \mathrm{MHz}\right) \delta$ $137.6(\mathrm{q}, J=281.8 \mathrm{~Hz}), 84.3(\mathrm{q}, J=29.7 \mathrm{~Hz}), 70.9,62.4$, 61.8, 31.3, 29.5, 17.3, 13.2. Anal. Calcd. for $\mathrm{C}_{11} \mathrm{H}_{20} \mathrm{~F}_{3} \mathrm{O}_{5} \mathrm{P}$ : C, 41.26; H, 6.29; Found: C, 41.19; H, 6.34; MS m/z 321 $(\mathrm{M}+\mathrm{H})^{+}$.

(rel)-(1'S,4'R)-Diethyl [9-(4'-trifluoromethylcyclopentanyloxy-1'-yl)-6-chloropurine] Methylphosphonate (11). DEAD (245 mg, $1.412 \mathrm{mmol}$ ) was added dropwise at -40 ${ }^{\circ} \mathrm{C}$ to a solution containing compound 10 (226 mg, 0.706 $\mathrm{mmol})$, triphenylphosphine (555 $\mathrm{mg}, 2.118 \mathrm{mmol})$, and 6chloropurine $(218 \mathrm{mg}, 1.412 \mathrm{mmol})$ in anhydrous THF (15.0 $\mathrm{mL}$ ) for $10 \mathrm{~min}$ under nitrogen. The reaction mixture was stirred for $4 \mathrm{~h}$ at the same temperature under argon and further stirred overnight at room temperature. The solvent was concentrated in vacuo and the residue was purified by silica gel column chromatography (EtOAc/hexane, 3:1) to produce compound 11 (206 mg, 64\%): mp 171-173 ${ }^{\circ} \mathrm{C}$; UV $(\mathrm{MeOH}) \lambda_{\max } 263.0 \mathrm{~nm} ;{ }^{1} \mathrm{H}$ NMR (DMSO- $\left.d_{6}, 300 \mathrm{MHz}\right) \delta$ $8.80(\mathrm{~s}, 1 \mathrm{H}), 8.33(\mathrm{~s}, 1 \mathrm{H}), 4.35(\mathrm{~m}, 1 \mathrm{H}), 3.84(\mathrm{~d}, J=8.2 \mathrm{~Hz}$ $2 \mathrm{H}), 3.75(\mathrm{~m}, 1 \mathrm{H}), 2.21-1.52(\mathrm{~m}, 6 \mathrm{H}), 1.12(\mathrm{~m}, 6 \mathrm{H}) ;{ }^{13} \mathrm{C}$ NMR (DMSO- $\left.d_{6}, 75 \mathrm{MHz}\right) \delta 151.7,151.6,151.4,145.2$, 137.6 (q, $J=282.8 \mathrm{~Hz}), 132.5,85.3$ (q, $J=28.6 \mathrm{~Hz}), 63.0$, $62.5,61.9,52.5,26.7,23.5,17.5,15.2$. Anal. Calcd. for $\mathrm{C}_{16} \mathrm{H}_{21} \mathrm{ClF}_{3} \mathrm{~N}_{4} \mathrm{O}_{4} \mathrm{P}(+1.0 \mathrm{MeOH}): \mathrm{C}, 41.83 ; \mathrm{H}, 5.16 ; \mathrm{N}, 11.48$; Found: C, 41.74; H, 5.25; N, 11.53; MS m/z $457(\mathrm{M}+\mathrm{H})^{+}$.

(rel)-(1'S,4'R)-Diethyl [9-(4'-trifluoromethylcyclopentanyloxy-1'-yl)-adenine] methylphosphonate (12). A solution of $11(220 \mathrm{mg}, 0.482 \mathrm{mmol})$ in saturated methanolic ammonia $(12 \mathrm{~mL})$ was stirred overnight at $72{ }^{\circ} \mathrm{C}$ in a steel bomb and the volatiles were evaporated. The residue was purified by silica gel column chromatography $(\mathrm{MeOH} /$ $\left.\mathrm{CH}_{2} \mathrm{Cl}_{2}, 1: 8\right)$ to produce $12(130 \mathrm{mg}, 62 \%)$ as a white solid: mp 163-165 ${ }^{\circ} \mathrm{C}$; UV (MeOH) $\lambda_{\max } 261.0 \mathrm{~nm} ;{ }^{1} \mathrm{H}$ (DMSO- $d_{6}$, $300 \mathrm{MHz}) \delta 8.28(\mathrm{~s}, 1 \mathrm{H}), 8.13(\mathrm{~s}, 1 \mathrm{H}), 4.37-4.34(\mathrm{~m}, 1 \mathrm{H})$, $3.87(\mathrm{~d}, J=8.1 \mathrm{~Hz}, 2 \mathrm{H}), 3.72(\mathrm{~m}, 1 \mathrm{H}), 2.19-1.49(\mathrm{~m}, 6 \mathrm{H})$, $1.11(\mathrm{~m}, 6 \mathrm{H}) ;{ }^{13} \mathrm{C}$ NMR (DMSO- $\left.d_{6}, 75 \mathrm{MHz}\right) \delta 155.5,152.7$, $150.5,141.4,137.3$ (q, $J=283.2 \mathrm{~Hz}), 120.1,86.1$ (q, $J=$ $30.2 \mathrm{~Hz}$ ), 62.6, 61.8, 52.2, 26.7, 22.5, 17.5, 13.9. Anal. Calcd. for $\mathrm{C}_{16} \mathrm{H}_{23} \mathrm{~F}_{3} \mathrm{~N}_{5} \mathrm{O}_{4} \mathrm{P}(+1.0 \mathrm{MeOH})$ : C, 43.52; H, 5.80; N, 14.93; Found: C, 43.65; H, 5.73; N, 14.85; MS $m / z 438$ $(\mathrm{M}+\mathrm{H})^{+}$.

(rel)-(1'S,4'R)-[9-(4'-Trifluoromethylcyclopentanyloxy1'-yl) adenine] 4'-Methylphosphonic Acid (13). TMSBr (0.619 mL, $4.69 \mathrm{mmol})$ was added to a solution of phosphonate 12 (205 mg, $0.469 \mathrm{mmol})$ in anhydrous $\mathrm{CH}_{3} \mathrm{CN}$ (10 $\mathrm{mL})$ and 2,6-lutidine $(1.09 \mathrm{~mL}, 9.38 \mathrm{mmol})$. The mixture was heated overnight at $72^{\circ} \mathrm{C}$ under nitrogen and then concentrated under vacuum. The residue was co-evaporated from concentrated aqueous ammonium hydroxide $\left(\mathrm{NH}_{4} \mathrm{OH}\right.$; $2 \times 20 \mathrm{~mL})$ and purified by triturating with acetone $(10 \mathrm{~mL})$ twice and removing the acetone by evaporation. The residue was then purified by preparative reverse-phase column chromatography using C18 silica gel. Lyophilization of the appropriate fraction produced phosphonic acid salt 13 (128 $\mathrm{mg}, 69 \%$ yield) as a white salt (ammonium salt): $\mathrm{UV}\left(\mathrm{H}_{2} \mathrm{O}\right)$ $\lambda_{\max } 262.0 \mathrm{~nm} ;{ }^{1} \mathrm{H}$ NMR $\left(\mathrm{D}_{2} \mathrm{O}, 300 \mathrm{MHz}\right) \delta 8.38(\mathrm{~s}, 1 \mathrm{H})$, $8.19(\mathrm{~s}, 1 \mathrm{H}), 3.81$ (d, $J=8.2 \mathrm{~Hz}, 2 \mathrm{H}), 3.72(\mathrm{~m}, 1 \mathrm{H}), 2.15-$ $1.51(\mathrm{~m}, 6 \mathrm{H}) ;{ }^{13} \mathrm{C} \mathrm{NMR}\left(\mathrm{D}_{2} \mathrm{O}, 75 \mathrm{MHz}\right) 155.7,152.9,150.8$, $141.6,138.5$ (q, $J=281.8 \mathrm{~Hz}), 120.5,85.9$ (q, $J=29.4 \mathrm{~Hz}$ ), 63.2, 52.2, 26.7, 22.5, 18.0; High-performace liquid chromatography $(\mathrm{HPLC}), t_{\mathrm{R}}=10.26 \mathrm{~min}$; High-resolution mass spectrometry (HRMS) $[\mathrm{M}-\mathrm{H}]^{+}$calcd. 380.0692, found 380.0693.

(rel)-(1'S,4'R)-Diethyl [9-(4'-Trifluoromethylcyclopentanyloxy-1'-yl)-2-fluoro-6-chloropurine] Methylphosphonate (14). Coupling of $\mathbf{1 0}$ with 2-fluoro-6-chloropurine was accomplished by using a similar Mitsunobu reaction as described for the synthesis of 11: yield 61\%; mp 176-178 ${ }^{\circ} \mathrm{C}$; UV (MeOH) $\lambda_{\max } 270.5 \mathrm{~nm} ;{ }^{1} \mathrm{H}$ NMR (DMSO- $d_{6}, 300$ MHz) $\delta 8.45$ (s, 1H), 4.21-4.15 (m, 4H), 3.81 (d, $J=10.5$ 
$\mathrm{Hz}, 2 \mathrm{H}), 3.69$ (m, 1H), 2.15-1.50 (m, 6H), $1.14(\mathrm{~m}, 6 \mathrm{H}) ;{ }^{13} \mathrm{C}$ NMR (DMSO- $\left.d_{6}, 75 \mathrm{MHz}\right) \delta 157.6(\mathrm{~d}, J=220.5 \mathrm{~Hz}), 154.1$, $145.2,137.3(\mathrm{q}, J=281.5 \mathrm{~Hz}), 136.5,121.3,86.7$ (q, $J=$ $30.4 \mathrm{~Hz}), 62.7,62.4,61.5,52.2,26.7,23.1,18.2$, 13.5. Anal. Calcd. for $\mathrm{C}_{16} \mathrm{H}_{20} \mathrm{ClF}_{4} \mathrm{~N}_{4} \mathrm{O}_{4} \mathrm{P}(+0.5 \mathrm{MeOH})$ : C, 40.43; $\mathrm{H}$, 4.52; N, 11.43; Found: C, 40.50; H, 4.48; N, 11.49; MS $m / z$ $475(\mathrm{M}+\mathrm{H})^{+}$.

(rel)-(1'S,4'R)-Diethyl [9-(4'-Trifluoromethylcyclopentanyloxy-1'-yl) 2-Fluoro-6-aminopurine] Methylphosphonate (15a) and (rel)-(1'S,4'R)-Diethyl [9-(4'-Trifluoromethylcyclopentanyloxy-1'-yl) 2-Amino-6-chloropurine] Methylphosphonate (15b). Dry ammonia gas was bubbled into a solution of 14 (310 mg, $0.65 \mathrm{mmol}$ ) in dimethoxyethane (15 $\mathrm{mL})$ while stirring at room temperature overnight. The salts were removed by filtration, and the filtrate was concentrated under reduced pressure. The residue was purified by silica gel column chromatography $\left(\mathrm{MeOH} / \mathrm{CH}_{2} \mathrm{Cl}_{2}, 1: 10\right)$ to produce $\mathbf{1 5 a}$ (35 mg, 12\%) and $\mathbf{1 5 b}(128 \mathrm{mg}, 42 \%)$.

Data for 15a: UV (MeOH) $\lambda_{\max } 261.0 \mathrm{~nm} ;{ }^{1} \mathrm{H}$ NMR (DMSO- $\left.d_{6}, 300 \mathrm{MHz}\right) \delta 8.21(\mathrm{~s}, 1 \mathrm{H}), 4.15-4.09(\mathrm{~m}, 4 \mathrm{H})$, $3.84(\mathrm{~d}, J=10.2 \mathrm{~Hz}, 2 \mathrm{H}), 3.70(\mathrm{~m}, 1 \mathrm{H}), 2.18-1.56(\mathrm{~m}, 6 \mathrm{H})$, $1.25-1.20(\mathrm{~m}, 6 \mathrm{H}) ;{ }^{13} \mathrm{C}$ NMR (DMSO-d, $\left.75 \mathrm{MHz}\right) \delta 160.9$ $(\mathrm{d}, J=254.3 \mathrm{~Hz}), 155.2,152.8,142.0,138.4$ (q, $J=281.4$ $\mathrm{Hz}), 120.2,85.4$ (q, $J=31.8 \mathrm{~Hz}), 63.2,62.7,61.7,52.7$, 26.8, 24.5, 19.2, 13.7. Anal. Calcd. for $\mathrm{C}_{16} \mathrm{H}_{22} \mathrm{~F}_{4} \mathrm{~N}_{5} \mathrm{O}_{4} \mathrm{P}(+1.0$ $\mathrm{MeOH})$ : C, 41.91; H, 5.38; N, 14.37; Found: C, 41.88; H, 5.43; N, 14.42; MS m/z $456(\mathrm{M}+\mathrm{H})^{+}$.

Data for 15b: UV (MeOH) $\lambda_{\max } 309.0 \mathrm{~nm} ;{ }^{1} \mathrm{H}$ NMR (DMSO- $\left.d_{6}, 300 \mathrm{MHz}\right) \delta 8.13(\mathrm{~s}, 1 \mathrm{H}), 4.17-4.14(\mathrm{~m}, 4 \mathrm{H})$, $3.84(\mathrm{~d}, J=8.0 \mathrm{~Hz}, 2 \mathrm{H}), 3.73(\mathrm{~m}, 1 \mathrm{H}), 2.17-1.57(\mathrm{~m}, 6 \mathrm{H})$, 1.24-1.20 (m, 6H); ${ }^{13} \mathrm{C}$ NMR (DMSO- $\left.d_{6}, 75 \mathrm{MHz}\right) \delta 158.4$, $154.1,150.7,142.7,136.9$ (q, $J=281.3 \mathrm{~Hz}), 125.2,86.3$ (q, $J=29.5 \mathrm{~Hz}), 62.6,62.1,61.5,53.7,27.6,23.2$, 13.7. Anal. Calcd. for $\mathrm{C}_{16} \mathrm{H}_{22} \mathrm{ClF}_{3} \mathrm{~N}_{5} \mathrm{O}_{4} \mathrm{P}(+1.0 \mathrm{MeOH}): \mathrm{C}, 40.58 ; \mathrm{H}$, 5.21; N, 13.92; Found: C, 40.62; H, 5.28; N, 13.87; MS $m / z$ $472(\mathrm{M}+\mathrm{H})^{+}$.

(rel)-(1'S,4'R)-[9-(4'-Trifluoromethylcyclopentanyloxy1'-yl) Guanine] 4'-Methylphosphonic Acid (16). Dry acetonitrile $(15 \mathrm{~mL}), 2,6$-lutidine $(1.01 \mathrm{~mL}, 8.72 \mathrm{mmol})$, and TMSBr $(0.57 \mathrm{~mL}, 4.36 \mathrm{mmol})$ were added to a solution of 15b (205 mg, $0.436 \mathrm{mmol}$ ) at room temperature. After stirring this mixture for $32 \mathrm{~h}$, the solvent was removed and co-evaporaed three times with $\mathrm{MeOH}$. The residue was dissolved in $\mathrm{MeOH}(16.0 \mathrm{~mL})$, and 2-mercaptoethanol (170 $\mathrm{mg}, 2.18 \mathrm{mmol})$ and sodium methoxide (117 mg, 2.18 mmol) were added to the mixture. The mixture was refluxed for $24 \mathrm{~h}$ under nitrogen, cooled, neutralized with glacial acetic acid, and evaporated to dryness under vacuum. The obtained residue was co-evaporated from concentrated $\mathrm{NH}_{4} \mathrm{OH}(2 \times 16 \mathrm{~mL})$ and the resultant solid was triturated with acetone $(2 \times 16 \mathrm{~mL})$. After evaporating the acetone, the residue was purified by preparative column chromatography by using reverse-phase C18 silica gel and eluting with water. Lyophilization of the appropriate fraction produced compound $16(92 \mathrm{mg}, 51 \%)$ in the form of a yellowish salt (ammonium salt): $\mathrm{mp} 180-182{ }^{\circ} \mathrm{C}$; $\mathrm{UV}\left(\mathrm{H}_{2} \mathrm{O}\right) \lambda_{\max } 255.5 \mathrm{~nm}$; ${ }^{1} \mathrm{H}$ NMR $\left(\mathrm{D}_{2} \mathrm{O}, 300 \mathrm{MHz}\right) \delta 7.84(\mathrm{~s}, 1 \mathrm{H}), 3.86(\mathrm{~d}, J=8.3$
$\mathrm{Hz}, 1 \mathrm{H}), 3.69(\mathrm{~m}, 1 \mathrm{H}), 2.19-1.60(\mathrm{~m}, 6 \mathrm{H}) ;{ }^{13} \mathrm{C} \mathrm{NMR}\left(\mathrm{D}_{2} \mathrm{O}\right.$, $75 \mathrm{MHz}) \delta 157.5,154.4,152.1,137.2,136.4$ (q, $J=280.8$ $\mathrm{Hz}), 119.1,86.3$ (q, $J=30.4 \mathrm{~Hz}), 63.4,44.6,24.1,18.4$; HPLC $t_{\mathrm{R}}=9.37 \mathrm{~min}$; HRMS [M-H] $]^{+}$req. 396.0754, found 396.0755 .

\section{References}

1. Boojamra, C. G.; Parrish, J. P.; Sperandio, D.; Gao, Y.; Petrakovsky, O. V.; Lee, S. K.; Markevich, D. Y.; Vela, J. E.; Laflamme, G.; Chen, J. M.; Ray, A. S.; Barron, A. C.; Sparacino, M. L.; Desai, M. C.; Kim, C. U.; Cihlar, T.; Mackman, R. L. Bioorg. Med. Chem. 2009, 17, 1739-1746.

2. (a) Ray, A. S.; Vela, J. E.; Boojamra, C. G.; Zhang, L.; Hui, H.; Callebaut, C.; Stray, K.; Lin, K. Y.; Gao, Y.; Mackman, R. L.; Cihlar, T. Antimicrob. Agents Chemother. 2008, 52, 648-654. (b) Boojamra, C. G.; Mackman, R. L.; Markevitch, D. Y.; Prasad, V.; Ray, A. S.; Douglas, J.; Grant, D.; Kim, C. U.; Cihlar, T. Bioorg. Med. Chem. Lett. 2008, 18, 1120-1123. (c) Cihlar, T.; Ray, A. S.; Boojamra, C. G.; Zhang, L.; Hui, H.; Laflamme, G.; Vela, J. E.; Grant, D.; Chen, J.; Myrick, F.; White, K. L.; Gao, Y.; Lin, K. Y.; Douglas, J. L.; Parkin, N. T.; Carey, A.; Pakdaman, R.; Mackman, R. L. Antimicrob. Agents Chemother. 2008, 52, 655-665.

3. (a) Okabe, M.; Sun, R.; Zenchoff, G. B. J. Org. Chem. 1991, 56, 4392-4397. (b) Fleet, G. W. J.; Son, J. C.; Derome, A. E. Tetrahedron 1988, 44, 625-636. (c) Patrick, T.; Ye, W. J. Fluorine Chem. 1998, 90, 53-55. (e) McAtee, J. J.; Schinazi, R. F.; Liotta, D. C. J. Org. Chem. 1998, 63, 2161-2167. (f) Lee, K.; Choi, Y; Gullen, E.; Schlueter-Wirtz, S.; Schinazi, R. F.; Cheng, Y. C.; Chu, C. K. J. Med. Chem. 1999, 42, 1320-1328. (g) Lee, K. C.; Choi, Y.; Hong, J. H.; Schinazi, R. F.; Chu, C. K. Nucleosides Nucleotides 1999, 18, 537-540.

4. (a) Hertel, L. W.; Kroin, J. S.; Misner, J. W.; Tustin, J. M. J. Org. Chem. 1988, 53, 2406-2409. (b) Xiang, Y.; Kotra, L. P.; Chu, C. K.; Schinazi, R. F. Bioorg. Med. Chem. Lett. 1995, 5, 743-748. (c) Fernandez, R.; Matheu, M. I.; Echarri, R.; Castillon, S. Tetrahedron 1998, 54, 3523-3532.

5. (a) Roy, A.; Schneller, S. W. Tetrahedron Lett. 2005, 46, 89138915, (b) Zhang, X.; Qing, F.-L. J. Org. Chem. 2002, 67, 10161019, (c) Jeannot, F.; Mathé, C.; Gosselin, G. Nucleosides Nucleotides Nucleic Acids 2001, 20, 755-758. (d) Jeannot, F.; Gosselin, G.; Standring, D.; Bryant, M.; Sommadossi, J.-P.; Loi, A. G.; Colla, P. L.; Mathé, C. Bioorg. Med. Chem. 2002, 10, 31533161. (e) Serafinowski, P. J.; Brown, C. A. Tetrahedron 2000, 56, 333-339.

6. Miethchen, R. J. Fluorine Chem. 2004, 125, 895-901.

7. Coderre, J. A.; Santi, D. V.; Matsuda, A.; Watanabe, K. A.; Fox, J. J. J. Med. Chem. 1983, 26, 1149-1152.

8. Hudlicky, M.; Pavlath, A. E., Eds.; Chemistry of Organic Fluorine Compounds II; American Chemical Society: Washington, DC, 1995.

9. Li, N.-S.; Tang, X.-Q.; Piccirilli, J. A. Org. Lett. 2001, 3, 10251028.

10. Kozak, J.; Johnson, C. R. Nucleosides Nucleotides 1998, 17, 2221-2239.

11. Wu, T.; Froeyen, M.; Kempeneers, V.; Pannecouque, C.; Wang, J.; Busson, R.; De Clercq, E.; Herdewijn, P. J. Am. Chem. Soc. 2005, 127, 5056-5065.

12. Kim, C. U.; Luh, B. Y.; Misco, P. F.; Bronson, J. J.; Hitchcock, M. J.; Ghazzouli, I.; Martin, J. C. J. Med. Chem. 1990, 33, $1207-$ 1213.

13. Kim, C. U.; Luh, B. Y.; Martin, J. C. J. Org. Chem. 1991, 56, 2642-2647.

14. Dess, D. B.; Martin, J. C. J. Am. Chem. Soc. 1991, 113, 72777287.

15. Lavaire, S.; Plantier-Royon, R.; Portella, C. J. Carbohydr. Chem. 1996, 15, 361-370. 
16. (a) Singh, R. P.; Shreeve, J. M. Tetrahedron 2000, 56, 7613-7632. (b) Stahly, G. P.; Bell, D. R. J. Org. Chem. 1989, 54, 2873-2877. (c) Prakash, G. K. S.; Krishnamurti, R.; Olah, G. A. J. Am. Chem. Soc. 1989, 111, 393-395. (d) Prakash, G. K. S.; Yudin, A. K. Chem. Rev. 1997, 97, 757-786.

17. (a) Phillion, D. P.; Andrew, S. S. Tetrahedron Lett. 1986, 27, 1477-1480. (b) Xu, Y.; Flavin, M. T.; Xu, Z.-Q. J. Org. Chem. 1996, 61, 7697-7701.

18. (a) Tanaka, M.; Norimine, Y.; Fujita, T.; Suemune, H.; Sakai, K. J. Org. Chem. 1996, 61, 6952-6957. (b) Liu, L. J.; Kim, S. W.; Lee, W.; Hong, J. H. Bull. Korean Chem. Soc. 2009, 30, 2989-2992.

19. Chong, Y. H.; Gumina, G.; Chu, C. K. Tetrahedron: Asymmetry 2000, 11, 4853-4875.
20. Hocková, D.; Holý, A.; Masojídková, M.; Keough, D. T.; De Jersey, J.; Guddat, L. W. Bioorg. Med. Chem. 2009, 17, 62186232.

21. Robins, M. J.; Uznanski, B. Can. J. Chem. 1981, 59, 2608-2611.

22. Montgomery, J.; Hewson, K. J. Med. Chem. 1969, 12, 498-504.

23. Tong, G. L.; Ryan, K. J.; Lee, W. W.; Acton, E. M. Goodman, L. J. Org. Chem. 1967, 32, 859-862.

24. Lian, L. J.; Yoo, J. C.; Hong, J. H. Nucleosides Nucleotides Nucleic Acids 2009, 28, 150-164.

25. Pauwels, R.; Balzarini, J.; Baba, M.; Snoeck, R.; Schols, D.; Herdewijn, P.; Desmyter, J.; De Clercq, E. J. Virol. Methods 1988, 20, 309-321. 